Estudios de

lingüística inglesa aplicada

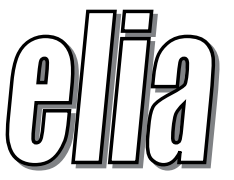

\title{
CODESWITCHING PRACTICES IN THE DISCOURSE OF TWO LECTURERS IN ENGLISH-MEDIUM INSTRUCTION AT UNIVERSITY
}

\section{LA ALTERNANCIA DE CÓDIGO EN EL DISCURSO DE DOS PROFESORES UNIVERSITARIOS EN LA INSTRUCCIÓN EN INGLÉS}

\section{Davinia Sánchez-García}

Universidad Complutense de Madrid, Spain

mdsgarcia@ucm.es

DOI: http://dx.doi.org/10.12795/elia.2018.i18.05

The present study focuses on analyzing the pedagogical functions of codeswitching (Milroy \& Muysken, 1995; Canagarajah, 1995, 2011; Auer, 1998; Bista, 2010; Garcia \& Wei, 2014) as one of the most pervasive compensatory strategies used by lecturers in English-medium instruction at university. The corpus examined includes 8 lectures taught in English by two different lecturers and belonging to two subjects within a Business Administration degree in Spain. Findings suggest that there seems to be four pedagogical purposes as the main motivators behind codeswitching practices. In addition, results indicate that the personal teaching style of lecturers and the nature of the academic disciplines are likely to largely determine the use of this compensatory strategy.

Key words: EMI, discourse strategies, codeswitching, classroom discourse, tertiary education

ELIA 18, 2018, pp. 105-135～DOI: http://dx.doi.org/10.12795/elia.2018.i18.05 
Este estudio analiza las funciones pedagógicas de la alternancia de código (Milroy \& Muysken, 1995; Canagarajah, 1995, 2011; Auer, 1998; Bista, 2010; García \& Wei, 2014) como una de las estrategias compensatorias más frecuentes en la instrucción en lengua inglesa. El corpus utilizado incluye 8 clases impartidas en inglés por dos profesores universitarios, las cuales pertenecen a dos asignaturas del grado en Administración y Dirección de Empresas en España. Los resultados obtenidos indican que la alternancia de código suele responder principalmente a cuatro funciones pedagógicas, y que tanto los estilos de enseñanza propios de cada profesor como la naturaleza de las disciplinas académicas parecen influir en los usos de esta estrategia compensatoria.

Palabras clave: English-medium instruction (EMI) o enseñanza en inglés como medio de instrucción, estrategias discursivas, alternancia de código, discurso del aula, educación superior

\section{Introduction}

In English-medium instruction (EMI) university contexts knowledge is shared and negotiated through a language other than the participants' first language (L1). The linguistic and communicative needs arising from such an educational scenario often impinge upon teachers' discourse practices (Dafouz, 2006; Smit, 2007; Dafouz \& Núñez, 2010; Nikula, 2010; Martín del Pozo, 2014; Moore, Márquez Fernández \& Gutiérrez Rando, 2014). For example, it seems that lecturers often draw on different communication strategies depending on the language used as the vehicle of instruction (Sánchez-García, 2016).

According to sociocultural theories (Wertsch, 1998; Lantolf \& Thorne, 2006), learning is conceived of as a social process that employs language as a complex and dynamic mediating tool that serves the interactants in their emerging communicative needs. Consequently, teachers become key classroom players since they are one of the primary sources that grant language access to their students by means of providing language and content input. It is precisely by means of teachers' verbal performances that students are exposed to those meanings that will be coconstructed in the classroom. For this reason, analyzing teacher discourse in terms of the manifold strategies that they deploy when delivering

ELIA 18, 2018, pp. 105-135 DOI: http://dx.doi.org/10.12795/elia.2018.i18.05 
academic knowledge through a second language (L2) ${ }^{1}$ is deemed to be illuminating so as to gain some insights on the linguistic needs that teachers are likely to be facing in their EMI teaching practices. One such discourse strategy is codeswitching (CS), which refers to the alternating use of more than one linguistic code in the classroom (Lin, 2013). In this line, this contrastive analysis aims at examining codeswitching practices as occurring in university teacher discourse so as to investigate more in depth the actual teaching motivations that make lecturers teaching through a L2 resort to codeswitching.

A theoretical reflection will be offered to explore the phenomenon of codeswitching, the pros and cons of its classroom use, and the perspective adopted in the study. This will pave the way for the presentation and interpretation of the data and the results obtained in the analysis.

\section{Defining Codeswitching}

Changing languages when communicating is everyday praxis for those people who speak more than one language. Its study probably dates back to Blom and Gumperz (1972), when it was first referred to as codeswitching. It has since been studied from a number of different perspectives; thus giving way to varied classifications and analyses (Poplack, 1980; MyersScotton, 1998; Unamuno, 2008) as well as a myriad of labels such code mixing, language selection, language alternation, codemixing, etc. The most relatively new term employed to make reference to the systematic alternate use of two or more languages is translanguaging. Although these terms can sometimes be found in the literature to address the same phenomenon, none of them is typically interchangeable as they represent concepts that rest on different theoretical positions. For instance, codeswitching implies shifting in and out of two separate codes often in a subconscious and automatic fashion (Modupeola, 2013). This claim has often resulted controversial for its realization of linguistic systems as clearly distinct instead of considering languages as dynamic and ongoing entities, which is in fact one of the assumptions of translanguaging. Translanguaging emerged in Wales as a deliberate pedagogical practice to develop language and content learning effectively (Williams, 2002; Baker, 2006). It supports the idea that bilinguals own an integrated repertoire built with all the linguistic systems they speak (García \& Wei, 2014). As a result,

ELIA 18, 2018, pp. 105-135～DOI: http://dx.doi.org/10.12795/elia.2018.118.05 
translanguaging goes well beyond the simple usage of two (or more) separate languages to also incorporate meaning making and accommodate speakers' personal history, experiences, attitudes and beliefs (Creese \& Blackledge, 2010; Wei, 2011; Cahyani et al., 2018). Therefore, translanguaging extends the scope of codeswitching and "captures the historical, political and social embeddedness of language practices and how these practices are and have been intertwined with ideologies" (Mazak, 2016, p. 3).

The perspective adopted in this study remains somehow in between the conceptualizations of both codeswitching and translanguaging, and will use the former term instead of the latter for various reasons. First, although codeswitching is considered to facilitate the teaching and learning process, it is barely used deliberately by lecturers other than as an impromptu compensatory strategy. Moreover, the two languages entailed in the switches (Spanish and English) do not work together as a unity for achieving communication, but rather tend to substitute one another to achieve the effective communication that will ultimately contribute to the successful learning of both disciplinary content and language. In this line, the study posits that, although in traditional educational contexts codeswitching has for a long time remained a contentious aspect for being considered the outcome of low language command, this phenomenon is a discourse strategy (Sánchez-García, 2016) that may turn out useful in the existence of linguistic difficulties, but which also serves other valuable pedagogical functions, as evidenced by the results unveiled in this study (see section 6).

\section{Classroom Codeswitching: Pros and Cons}

Research on classroom codeswitching as occurring in EFL classroom abounds (Guthrie, 1984; Duff \& Polio, 1990; Simon, 2001; Levine, 2011; Li, 1998, 2005; Jingxia, 2010; Then \& Ting, 2011; Lin, 2013) and usually evolves around dissenting opinions that often stand on whether alternating the use of students' foreign and target language (TL) and their L1 may be conducive to TL learning or may actually hinder it.

On the one hand, sociocultural theories of learning (Vygotsky, 1978, 1986), for example, consider codeswitching as a scaffolding strategy that

ELIA 18, 2018, pp. 105-135 DOI: http://dx.doi.org/10.12795/elia.2018.i18.05 
also works as a psychological tool. They lay the foundation of such belief on the fact that the L1 may offer students additional cognitive support that allows them to analyze language and work at a higher level than would be possible if they were limited to the sole use of the L2 (Storch \& Wigglesworth, 2003). Further research also supports the use of the L1 as a beneficial learning strategy in that it usually turns difficult tasks into more manageable and often creates "a social and cognitive space in which learners are able to provide each other and themselves with help throughout the task" (Wood, Bruner \& Ross, 1976, p. 338); therefore, extending students' Zone of Proximal Development (ZPD). ${ }^{2}$

In this line, codeswitching is also thought to be a natural language facilitator (Swain \& Lapkin, 2000; Scott \& de la Fuente, 2008) that makes communication feasible between classroom participants and provides students with the opportunity to exchange information that would otherwise not be expressed. It is in fact at these points of apparent communicative difficulty, when "the cost of the target language is too great" (Cook, 2001), that using the $\mathrm{L} 1$ could be allowed and resorted to.

Another major reason put forward to justify the use of the L1 in the language classroom is the claim that students often tend to build on their L1 knowledge as a first stage from which to construct their TL linguistic system. As a consequence, it could be the case that overtly employing their L1 may help students navigate through the TL system, ultimately easing its use (Stern, 1992).

On the other hand, one of the claims advocating for TL-only classrooms focuses on the importance of the quantity and quality of the TL input that students are exposed to. Lightbown (2001) maintains that teachers are typically the prime linguistic models for students, therefore, they should provide learners with as much input and as many language functions as possible in that TL. For this reason, it is often believed that the (over)use of students' L1 will significantly reduce the time devoted to the TL exposure, thus, truncating its learning process. Besides, this deprivation of valuable TL input may even result in negative transfer from the students' L1 to the FL (Ellis, 1984).

In addition, switching from the TL to the L1 may also frustrate students' learning process because it often entails decreasing the number of situations where students would experience unpredictability and would develop their own in-built TL system (Halliwell \& Jones, 1991, p. 1).

ELIA 18, 2018, pp. 105-135～DOI: http://dx.doi.org/10.12795/elia.2018.i18.05 
McDonald (1993) also remarked that focusing on the use of the TL may make students run language risks that will lead them to become more confident when communicating through the TL in spite of their possible limited resources to do so.

If codeswitching practices seem to be a double-edged sword in EFL contexts, its pros and cons may be even more accentuated in EMI contexts, where English, the language through which the negotiation of disciplinary content is realized, becomes a lingua franca (ELF) and is no longer the subject of study in the classroom. Codeswitching may be one of many discourse practices that have the potential to assist the lecturers in the successful fulfillment of their communicative and pedagogical objectives; however, it may also lose its effectiveness due to specific characteristics of the educational context in which it is articulated (Sánchez-García, 2016). EMI at university entails the negotiation and co-construction of discipline knowledge through a lingua franca, i.e., a linguistic system that is shared by classroom participants with different L1 and differing linguistic and cultural backgrounds. Under these circumstances, although changing languages may bring about all the pros aforementioned, it may also pose additional challenges to those students who may not have enough competence of the L1 that serves as the vehicle of communication and as the access to disciplinary knowledge. Thus, the potential learning gains that codeswitching is likely to facilitate cannot always be taken for granted.

\section{Aims of the Research}

Now that EMI is blooming as a response to globalization and the internationalization of universities (Leask, 2015), studies regarding classroom discourse in higher education are of much help to unravel the reality and the pressing needs that such educational scenario may be posing on teachers and students. Teachers lecturing through their L2 tend to exhibit fair language competence within their academic discipline and classroom domains. However, the communicative competence in their L2 is often less perfectly developed than in their L1. Under this circumstance, it seems to be the case that codeswitching often appears as a pervasive discourse strategy to assist lectures in their achievement of their intended communicative and pedagogical goals (Kasper \& Kellerman, 1997; Dörnyei \& Scott, 1997; Sánchez-García, 2016). This research then tries to

ELIA 18, 2018, pp. 105-135～DOI: http://dx.doi.org/10.12795/elia.2018.118.05 
add to current investigations on the phenomenon of codeswitching (Hall \& Cook, 2012; Barnard \& McLelland, 2014; Mazak \& Carroll, 2016; Smit, 2018) by giving answer to the following research questions:

RQ1: What are the main pedagogical purposes behind the codeswitching practices that take place in English-medium instruction in higher education?

RQ2: Do lecturers' codeswitching practices in English-medium instruction in higher education make similar use of those pedagogical functions?

\section{Methodology}

\subsection{Corpus and Participants}

This paper sets out to explore the phenomenon of codeswitching as it naturally occurs in university EMI to shed some light on the discourse practices that such an academic context demands. Therefore, this predominantly qualitative study tries to examine the pedagogical functions behind teachers' language alternation in EMI lectures.

In order to carry out this research objective, a corpus of eight lectures delivered by two different university lecturers (four lectures each) has been collected; thus offering a contrastive study. As Table 1 illustrates, the total corpus accounts for 671 minutes of teaching practice and comprises 65,342 words. The eight lessons are given through English, which works as the FL of the teacher and $\operatorname{most}^{3}$ of the students attending the lessons, and therefore, as the classroom lingua franca since not all participants share their L1.

\begin{tabular}{|c|c|l|c|c|}
\hline & Lecture & \multicolumn{1}{|c|}{ Topic } & Minutes & Words \\
\hline \multirow{2}{*}{$\begin{array}{c}\text { Lecturer } \\
\text { A }\end{array}$} & 1 & Attitudes in commercials & 85 & 7037 \\
\cline { 2 - 5 } & 2 & $\begin{array}{l}\text { Consumer motivations in } \\
\text { advertising }\end{array}$ & 86 & 7841 \\
\cline { 2 - 5 } & 3 & $\begin{array}{l}\text { Family and social influences in } \\
\text { advertising }\end{array}$ & 78 & 7894 \\
\cline { 2 - 5 } & 4 & Social class in advertising & 72 & 8872 \\
\hline
\end{tabular}

ELIA 18, 2018, pp. 105-135 DOI: http://dx.doi.org/10.12795/elia.2018.i18.05 


\begin{tabular}{|c|c|l|c|c|}
\hline & Lecture & \multicolumn{1}{|c|}{ Topic } & Minutes & Words \\
\hline \multirow{2}{*}{$\begin{array}{c}\text { Lecturer } \\
\text { B }\end{array}$} & 5 & The income statement & 101 & 8637 \\
\cline { 2 - 5 } & 6 & Seminar: SABI database & 46 & 4295 \\
\cline { 2 - 5 } & 7 & Book keeping & 99 & 10054 \\
\cline { 2 - 5 } & 8 & $\begin{array}{l}\text { Accounting books: The journal } \\
\text { and the ledger }\end{array}$ & 104 & 10712 \\
\hline & & 671 & 65342 \\
\hline
\end{tabular}

Table 1. Corpus collection

Each lecturer is responsible for teaching a different academic field within a Business Administration degree offered at a university in Madrid (Spain). The four lectures delivered by Lecturer A are part of a course called Consumer Behavior (CB), and the four lectures given by Lecturer B deal with Financial Accounting (FA). The language proficiency of the two teachers corresponds to the $\mathrm{C} 1$ level (CERF), and their teaching experience varies. At the time of the study, Lecturer $\mathrm{A}$ had been teaching Consumer Behavior for three years, and Lecturer B had been teaching Financial Accounting for 5 years.

The cohorts of students are medium-sized (around 20 - 50 students per lesson), and heterogeneous. Although in both courses there is a fairly mixture of local Spaniards and Erasmus students, in $\mathrm{CB}$, the percentage of learners coming from different European countries is approximately $80 \%$. In contrast, foreign students in FA represent a rough $40 \%$.

\subsection{Taxonomies and Data Analysis}

The present study is interested in investigating the pedagogical functions fulfilled by codeswitching practices in EMI lectures at tertiary level. For that purpose it draws on the taxonomy put forward by Cahyani et at. (2018) which, basing on Ferguson's prior classification (2003, 2009), distinguishes between four pedagogical and functional categories of codeswitching:

ELIA 18, 2018, pp. 105-135 DOI: http://dx.doi.org/10.12795/elia.2018.i18.05 
1. CS for knowledge construction (CS1): including pedagogical scaffolding of content lessons, conceptual reinforcement, annotation of key L2 technical terms, and review of a topic.

2. CS for classroom management (CS2): ranging from a topic shift/ footing in lesson content to management of student behavior such as developing self-awareness, gaining attention, and reprimanding/ chiding.

3. CS for interpersonal relations (CS3): including indexing and negotiating different sociocultural identities, and humanizing the classroom climate such as by giving praise and establishing rapport.

4. CS for personal or affective meanings (CS4): covering teachers' personal experiences, feelings, and sociocultural functions such as saving face.

After the informed consent of all participants, lectures were recorded, videotaped and manually transcribed following the transcription codes proposed by Du Bois, Schuetze-Coburn, Cumming and Paolino (1993). Afterwards, complying with inter rater reliability, all the instances of codeswitching were identified and scrutinized taking into account the context in which they appeared so as to discover the motivation behind their use and their pedagogical function. They were then tagged according to the taxonomy proposed by Cahyani et al. (2018). In case different tags were given to the same instances of codeswitching, a further, more sensitive, analysis was carried out to clarify and agree on the final category. The audio and video transcriptions were complemented with in-classroom observation. Therefore, in order to ensure the study's validity and reliability a combination of ethnographic observation and close analysis of discourse have been brought together (Nilep, 2006).

After explaining the methodology of this research, the results obtained in the contrastive examination of codeswitching practices by two different lectures and in two different academic disciplines will be provided in detail so as to discover their actual pedagogical functions, first as a general analysis of codeswitching, then as a cross-case synthesis (Yin, 2003).

ELIA 18, 2018, pp. 105-135 DOI: http://dx.doi.org/10.12795/elia.2018.i18.05 


\section{Results and Discussion}

In the corpus analyzed, a total number of 221 instances of codeswitching has been identified. As shown in Graph 1, the pedagogical purposes behind the use of language switches seem to be, first, to construct disciplinary knowledge; second, to manage the classroom; third, to realize personal or affective meanings; and finally, to establish personal relationships between classroom participants.

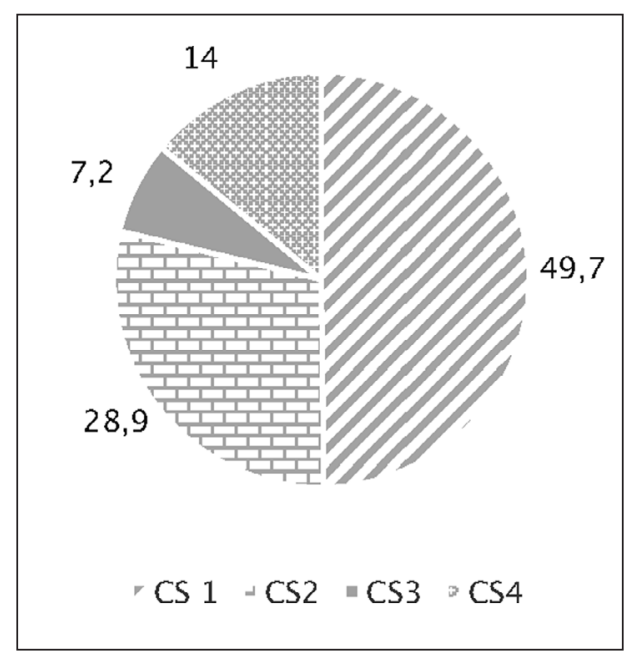

Graph 1. Types of codeswitching (\%)

In what follows, instances of codeswitching from the data analyzed will be illustrated from the most to the least pervasive ones so as to support the numerical findings just shown.

\subsection{Codeswitching for Knowledge Construction (CS1)}

Changing from English to Spanish for knowledge construction seems to be the most frequent pedagogical purpose behind the use of codeswitching, and there seem to be five particular scenarios to be subsumed in this category.

ELIA 18, 2018, pp. 105-135 DOI: http://dx.doi.org/10.12795/elia.2018.i18.05 
To start with, teachers resort to this discourse strategy when they cannot find the appropriate English word to match the meaning they would like to convey. As exemplified in Example 1, the teacher typically produces the Spanish equivalent of those words or expressions which she cannot come up with as her discourse unfolds. In these scenarios, students tend to provide the corresponding piece of language in English. It seems that the lecturer's strategy is to use the Spanish version in the form of an interrogative, which calls for interaction and makes students assist her and get involved in the conversation. In Example 2, instead of asking for a specific word, the teacher seeks confirmation from the students. She needs to make sure that "warranty" conveys the correct meaning in the context she is talking about.

(1) T: We know that hamburgers with fries and Coca Cola is not the best meal that you can have for lunch every day, but what would happen if you to go a... ¿pastelería? (..2)

S: Bakery

T: Bakery and spend a week just eating croissants, chocolate and eating Coca Cola?

(2) $\mathrm{T}$ : So if $y$ - if we are taking the decision to purchase certain brand in our evaluation process we will take into account that this brand really takes care of the environment. The other one doesn't. For example, the number of years of warranty, garantia

S: Warranty

T: Warranty yeah.

In other occasions, the word needed is simply replaced by the Spanish counterpart and the speech continues without the teacher's apparent interest in finding the appropriate way of expressing the idea in the corresponding language. At these points it could be the case that the teacher does not feel like breaking the pace of the lecture by disrupting the discourse to ask for help. Exceptions usually resemble Example 3, in which right after uttering the word in Spanish (adrenalina) the teacher is able to retrieve the English equivalent.

(3) T: Well, it's it's much more aggressive in the in the- it's intense. You can feel the adrenalina, the adrenaline, so it's really targeted at at young people.

ELIA 18, 2018, pp. 105-135 DOI: http://dx.doi.org/10.12795/elia.2018.i18.05 
Interestingly, as seen in these examples, it is common to find that the type of language the lecturer consistently needs help with is not the academic language of the discipline, but rather the social language that is expected when negotiating everyday situations or experiences ('bakery', 'warranty', 'adrenaline', 'olive', 'laundry detergent', etc').

When constructing knowledge, it is also often the case that the prime sources of information used as central materials in this subject are rendered in a particular language, which eminently influences a shift of code to accommodate that material and make reference to it.

(4) T: How do you say "alimenta sonrisas"? Feed? Feeds? S: Feeds your... T: Feeds smiles? Keep smiling. So Danone has that smiles and speaks about family, about being happy

(5) T: "Tus defensas también tienen que desayunar". Your defenses also have to take breakfast. So... please, in the morning. Take an Actimel, drink an orange juice and hav- take some cereals. There was a very famous campaign run by Danone

(6) T: And we are going to enter in the library webpage. Biblioteca, in the library, go there to the library. And then click on base de datos, in database. And then write SABI.

In Examples 5 and 6, the class is analyzing two different commercials originally broadcast in Spanish. The teacher attempts to translate the slogans of the brands to maintain English as the medium of instruction and probably to also facilitate the comprehension of those students who are not native speakers of Spanish and may not be able to grasp the point being argued in class. Sometimes she obtains students' help and they arrive at an understandable version of the original idea (Example 4), while some other times she manages with a literal translation into English (Example 5).

Example 6 comes from a practical lesson held in the computer lab. The main objective of the class is to learn how to use a database called SABI and since it is set up in Spanish by default, the teacher has to make explicit reference to the different computer search menus in that language. However, as seen in Example 6, she also tries to translate the labels into English ("And then click on base de datos, in database").

ELIA 18, 2018, pp. 105-135～DOI: http://dx.doi.org/10.12795/elia.2018.i18.05 
A third interesting use of codeswitching for knowledge construction is supported by Example 7, where it may be quite clear that the teacher's intention is to provide the Spanish equivalent of the most technical terms pertaining to the field. It could be postulated that, although students have decided to study this academic subject in English, the lecturer's deliberate decision to offer terminology in both languages, not regularly but punctually with the most troublesome concepts, could foster and increase students' understanding of the academic field. Since this explicit and intentional tendency towards offering key concept equivalents in Spanish is well established and accepted in the lectures, sometimes it is the students who elicit codeswitching practices by asking for the counterpart lexis in the other language, as in Example 8. This may be indicative of the potential usefulness that students themselves find in codeswitching practices.

(7) T: We call each transaction entry. Ok? In Spanish we call asiento. Like a chair. This is an entry, this is another entry so in the journal we will see only entries.

(8) T: If If If I say if I say the company invoic- who who do the invoice? Who prepare the invoice? S: ... What's in English? (he meant in Spanish) T: Factura. The notes to pay. The right that the company have to collect the money.

There is also an interesting tendency on the part of the teacher to speak in Spanish when she does not really follow students' contributions or arguments, especially when they somehow deviate from the main topic being developed. In this way she avoids getting lost in the flow of conversation.

(9) S: Jamie Oliver wanna try against...

T: Who?

S: ...Jamie Oliver.

T: ¿Quién es Jamie Oliver?

SS: [[A famous chef in the United States]]

T: ¿Qué?

S: Vende hasta tablas de madera

(10) T: That's not what you are expecting. You are expecting someone sitting on a truck, not eeehhh doing equilibrios. I think it's a good

ELIA 18, 2018, pp. 105-135～DOI: http://dx.doi.org/10.12795/elia.2018.i18.05 
ad. Yeah, of course it's not directed to the mass consumption market, but I think they make the point in a really very simple way.

S: Last ad they did it with a ballerina eehh between two trucks.

T: Esonolo he entendido. I need in Spanish.@@@ I didn't get...

I I can't understand what you you the example, but it's my problem with my- with the English.

As observed in Example 9, the main line of discussion, which was McDonalds' change of image, has departed from general features and has become a little too detailed commenting on how a famous chef has sued the company for an allegedly unhealthy treatment of food. The teacher is not acquainted with this famous cook and she asks students to explain. The first answer provided by a student is given in English; yet, the teacher persists in her use of her L1, somehow forcing the student to produce a codeswitch too. Example 10 provides a scenario in which the teacher confirms that she cannot understand her student's comment about the commercial being analyzed and explicitly states that she is facing language difficulties.

Likewise, teachers also seem to feel an overwhelming urge to change into their L1 when they have the intuition that students are not following them or they themselves experience the feeling of having delivered a relatively obscure speech that might not be clear for the learners.

(11) T: It was a search tool. Did it have any advertising in the TV? Or was something that you just wrote down in a computer and... "I'm going to see what Tripadvisor says about the hotel that I'm..... want to go... on holidays". But we didn't have a perception of the brand as it was a funny brand or was it just a search tool? (..2)

No se entiende lo que digo, ¿no?

$\mathrm{S}:$ [Si]

S: It's like... you wanted to... communicate [a feeling...]

(12) S: What's the message?

$\mathrm{T}$ : The message is that that... let me take a look at what she said.

(Commercial being played again)

T: ¿Recibe usted bien la señal? How would you say... what is this?

SS: Signal

ELIA 18, 2018, pp. 105-135 DOI: http://dx.doi.org/10.12795/elia.2018.i18.05 
T: Yeah. I mean, it's the signal. Eeehhh do you get the... yeah, the signal for TV or what. It's quite difficult for me to explain it in English. Yes.... The signal of the... the TV signal was eehhh had problems in the sixties because you didn't get a correct image. Is the signal of the antena... ¿Alguien se lo puede.. explicar en inglés correctamente?

In Example 11, the teacher is explaining the evolution of an internet search engine and she has the feeling that her students may not be following her, so she draws on the L1 to verify whether she is making herself understood. Students respond that they do understand in Spanish and immediately try to rephrase the teacher's explanation to make clear that they are on the same page. In Example 12, they have just seen a commercial dealing with TV reception and the teacher clearly struggles to explain the hidden meaning of the ad to her Erasmus students since it is rooted in the Spanish culture. Therefore, she switches to her L1 to ask for a volunteer who could explain the commercial in English so that foreign students can follow and understand.

Consequently, when culture matters emerge during the construction of knowledge, there seems to be no other choice but to communicate cultural meanings through the language of that culture; thus, switching to the L1 is deemed necessary. As described by Example 13, aspects of Spanish culture ('sangria', 'tortilla de patatas', 'flamenco') are brought up as a topic and translations do not seem to be effective to convey the same meaning as the actual L1 words. Thus, Spanish is used in these communicative situations and, as the concepts are well-known, there seems to be no failure of understanding or any need to provide an English approximation.

(13) T: Did you think there were... like funny people you can have fun with them, they they were- they went out, they stayed late at night? And... Spain and la fiesta. I think they are almost linked, aren't they?

S: Y la sangría

T: Y la sangría. La tortilla de patatas

S: El flamenco

T: El flamenco. So no attitudes.

ELIA 18, 2018, pp. 105-135 DOI: http://dx.doi.org/10.12795/elia.2018.i18.05 


\subsection{Codeswitching for Classroom Management (CS2)}

Teachers' codeswitching for classroom management is the second most pervasive pedagogical purpose that triggers teachers' change of linguistic code in class. It usually takes place when there is a change or transition of activity in the lesson. Example 14 shows how it seems to be recurrent to use the $\mathrm{L} 1$ whenever there is an aside or the main subject matter takes a detour.

\section{(14): T: Do you agree with her? (..1) S: I... I I don’t agree [with her] \\ $\mathrm{T}$ : [You don't agree with her] (A cell phone rings) ¿Llamada urgente? ¿No? Era la alarma.}

In addition, the Spanish language looks like the most convenient code when technical problems are encountered and the structure or pace of the lesson are disturbed by unforeseen circumstances, as seen in Example 15 and 16. This is also the case when lecturers have to tell their students off, usually for not paying attention, talking too much or distracting their classmates (Example 17).

(15) We are going to finish with this eehh chapter definitely today and eehh well we've seen that attitudes can be eehh ¿qué le pasa a esto? (referring to the computer) Bueno...

(16) (Teacher tries to play another commercial) T: ¿Por qué no entra? ¿Qué me has dicho?

S: Control Alt

T: ¡Ah ya! pero eso ya lo he hecho, eso no entra. Ya. Thank you.

(17) T: I don't know exactly how much these are. ¿Queréis callaros? Ya, o sea ya voy a decir tacos. ¡Que os calléis! ¿En qué lo digo?

Teachers' switching to the L1 when scolding students may be indicative of the power that the L1 exerts in one's personality. In a very subtle way it could be observed that, although students may not be affected by the language used, the teacher is likely to feel a higher authority status and a stronger empowerment when admonishing through her L1 in the light that it seems to inject her with more character and strength; thus showing her disapproval, determination and seriousness regarding the situation involved. Similar results were discovered by Wilkerson (2008)

ELIA 18, 2018, pp. 105-135 DOI: http://dx.doi.org/10.12795/elia.2018.i18.05 
when investigating teachers' use of English (L1) in Spanish (L2) classroom contexts.

\subsection{Codeswitching for Personal or Affective Meanings (CS4)}

Expressing personal or affective meanings seems to be teachers' third most frequent rationale for drawing on codeswitching. There are three main scenarios when this pedagogical purpose is fulfilled through CS. The first of them makes reference to instances of inner speech (Vygostky, 1986; Lantolf \& Thorne, 2006), that is, when the lecturers talk to themselves either out loud or in a low voice. This use was also identified in Storch \& Wigglesworth's (2003) study. In Example 18 the teacher has just collected students' ratings of several beverages as part of a blind test and she reads the results to herself while she writes them on the blackboard for students to see. In the same vein, in Example 19, the teacher is looking for the link to a commercial that she would like to play and she asks herself about the whereabouts of that link using her L1.

(18) T: (Reading to herself) Marca blanca, marca blanca, Pepsi, marca blanca, Coca Cola.

(19) T: Alright. Ok, let's choose (..2) ¿Dónde está esto?

Apart from this, it is often the case that teachers express their opinion about the topic at hand or what is going on in the classroom by overtly switching to the L1. This happens as a way to share their own life experiences or points of view considering them valuable for students' learning. In other occasions lecturers spell out their impromptu feelings. Such is the case in Example 20, where students do not stop speaking while the teacher is explaining and, as the result of being annoyed and frustrated with their students' misbehavior at the moment of speaking, she automatically moves to the L1 to show that she is upset.

(20) T: This is the example of Samsung. I think it's good. I think it's better. And now it's really better eehhh through their mobile phones. I'm speaking about, I don't know, about fifteen years ago when when- and what was the ¡oh qué coñazo de gente!

ELIA 18, 2018, pp. 105-135～DOI: http://dx.doi.org/10.12795/elia.2018.118.05 
The third scenario of the pedagogical use of codeswitching for expressing personal affective meanings is closely related to teachers' saving face, that is, to avoid showing uncomfortable or embarrassing situations to the students. In Example 21 the teacher is going to provide some examples as part of the theory being explained but something completely different appears in the slides. She realizes it has nothing to do with what they are talking about, saying so in her L1, and decides to change the topic hastily. In the case of Example 22, it is one student who highlights a mistake in the rating the teacher is giving to some comments. The lecturer switches to the L1 to wonder what is wrong until she finds out and then goes back to English again.

(21) T: Let me show you some examples. Esto no sé lo que es, but... (Teacher goes through the slides of her presentation. Finally she moves on)

(22) T: If that brand doesn't convince the mum because it's a good quality, she will never buy it. She will be the decider. That's the mum. And eehhh who would be the consumer? The child again. (Teacher is writing the answers on the blackboard) It comes$\mathrm{S}$ : That's wrong. The consumer is five (Teacher wrote the wrong number on the blackboard)

T: Pardon?

$\mathrm{S}$ : The consumer is five

T: ¿Qué he dicho? No sé qué he dicho. The decider is the mum. Ah! The buyer is the mum. Alright. And the decider is the child. (She corrects the number on the blackboard)

\subsection{Codeswitching for Interpersonal Relations (CS3)}

Resorting to codeswitching to index and negotiate different sociocultural identities and humanizing the classroom is a scarce practice in all the lectures analyzed and the situations in which languages are shifted for such pedagogical purpose have more to do with creating a supportive classroom atmosphere and improving the rapport between classroom participants. It is common to discover that students' oral contributions tend to be extended and encouraged by the teacher, who changes to the L1 precisely to show her interest in students' comments and to foster

ELIA 18, 2018, pp. 105-135～DOI: http://dx.doi.org/10.12795/elia.2018.118.05 
participation. Likewise, the teacher seems to be in the dark about topics which happen to be slight detours of the main course of the conversation and, instead of redirecting students' output, she switches to Spanish to obtain further explanation from her students. In this way, she becomes familiarized with the new topic while she welcomes learners' participation and fosters a close and harmonious relationship between herself and the students. This is illustrated in Example 23, where the analysis of several commercials leads students to talk about Paypal.

(23) T: He's the the owner of the company is the owner of the idea

Paypal?

S: No, Paysec

$\mathrm{T}$ : ¿Eso qué es?

Codeswitching also takes place during negotiations of meaning, not only regarding the content of students' asides, but in relation to language. As unveiled in Example 24 with the term 'red-neck', students are likely to use certain expressions and vocabulary that are often not part of the linguistic repertoire of the lecturer, leading her to ask about their meaning.

(24) S: I think that you can be like not very well educated and still have money so that doesn't mean you're gonna be upper class. For example a red-neck is still gonna stand up.

T: ¿Qué es a red-neck? (..2) A red-neck? (Teacher repeats without actually knowing the word)

$\mathrm{S}:$... A red-neck

T: Es que no sé...

$\mathrm{S}:$ Un paleto

T: ¡Ah! Un paleto. I didn’t know the word. Now I know.

In the case of Example 25, the teacher is conducting an experiment in class and asks for a volunteer to help her write the results on the blackboard. She codeswitches to explain to him how to proceed and then also to overtly express her opinion on the results using very colloquial L1 language (iqué alucine!). This is a clear instance of codeswitching for expressing personal and affective meanings. In fact, one of the students, surprised by the teacher's remark, asks her if they have done it all wrong. The teacher's reply still in the L1 affirms that he has been the only one answering correctly and that is why she is amazed. Then she keeps using

ELIA 18, 2018, pp. 105-135～DOI: http://dx.doi.org/10.12795/elia.2018.i18.05 
Spanish to praise the student while she bonds and improves the classroom rapport through her use of L1 jargon. After that encouraging exchange she moves back to English.

(25) T: Can you help me? (To the student that is writing results on the blackboard) ¿Cómo hacemos? ¿Ponemos las puntuaciones?

S: Ah, si...

$\mathrm{T}$ : Ponemos las puntuaciones y solamente ponemos los que dicen que saben la marca (...) ¡Qué alucine, ¿no?

S: ¿Por qué? ¿Lo dijimos todos mal?

T: Tú eres el único que lo has hecho bien

S: ¿Si?

T: Exactamente bien. O sea, por eso me has dejado alucina

\subsection{Contrasting Use of Teachers' Codeswitching}

When approaching the data, similar uses of codeswitching were expected to be identified in all the EMI lessons, irrespective of the lecturer, based on the assumption that this practice is the result of using an L2 as the vehicle of instruction. This fact could lead to equivalent communicative situations that may trigger the strategic employment of codeswitching by both lecturers. However, lecturers seem to make utterly contrasting uses of this strategy.

As unraveled in Graph 2, Lecturer A is the one that most recurrently draws on codeswitching for pedagogical purposes. In fact, her speech unfolds 3,86 instances of language alternation per 1000 words; in contrast with Lecturer B whose discourse contains 0,97 cases. A more detailed account of the phenomenon of codeswitching as used by each lecturer individually is presented in Graph 3 and 4.

Lecturer A's most characteristic types of codeswitching include stepping out of delivering subject contents and remaining closer to the backstage phases of the lecture, like asides, managing students' behavior and collaboration as well as talking to herself and trying to come to grips with students' expressed ideas as they become intertwined with the lecture itself (see Graph 3). However, above all these pedagogical aims, Lecturer A is the one presenting the highest number of linguistic difficulties in the L2. Therefore, the prime objective of her codeswitching is to elicit students'

ELIA 18, 2018, pp. 105-135 DOI: http://dx.doi.org/10.12795/elia.2018.118.05 


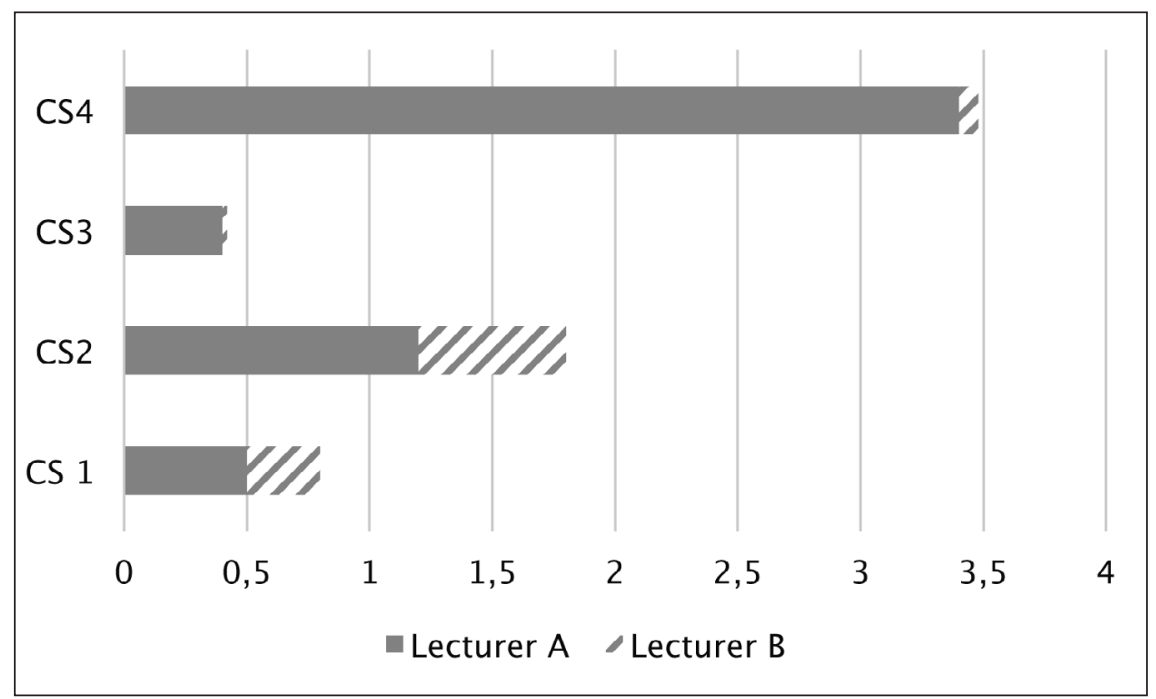

Graph 2. Lecturer A vs Lecturer B's CS (\%o)

language help and support and to ask about the particular concepts that are deemed necessary to explain and negotiate disciplinary contents. As a result, it could be claimed that Lecturer A's use of codeswitching often paves the way for a more egalitarian and participatory classroom methodology and atmosphere in EMI. Students now become informants in the lectures as well. Teachers are content experts and not necessarily language specialists; therefore, they can resort to their students' knowledge on the language to not only apply and learn new words, but to create interaction, stimulate learners' interest and, to a greater extent, deliver and negotiate contents. This may also be invigorating and comforting for EMI lecturers, who can become aware of the fact that they do not need to have a constant and strong grip on every aspect of the lecture. At least in reference to the language of instruction, they can always be assisted by students so that the teaching and learning experience becomes an enriching two-way process.

Conversely, the most noticeable uses of codeswitching in Lecturer B's discourse are associated, first of all, with the language of the tools that they handle in the course and, second of all, with the deliberate comparison of specialized terminology in both languages (see Graph 4). Codeswitching 


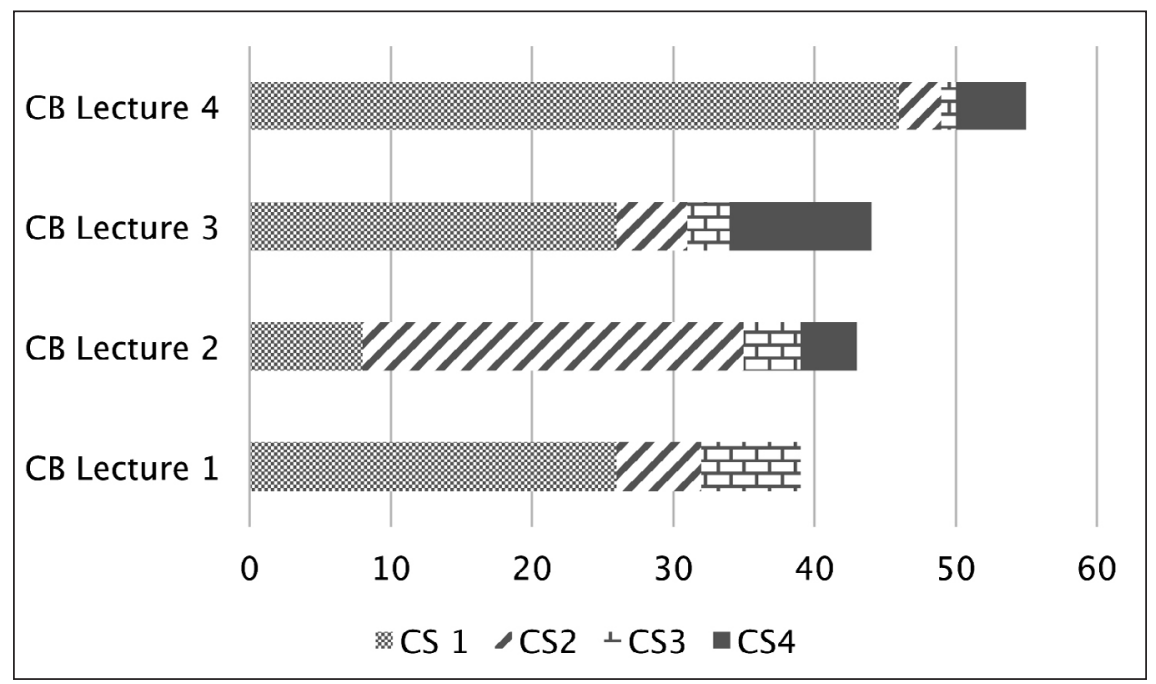

Graph 3. Codeswitching in Lecturer B's discourse (n)

never happens to occur as the result of Lecturer B's lack of linguistic resources. She always seems to manage to express herself and convey the subject contents through English without having to ask for students' assistance with language. This fact may be attributable to the nature of the academic field, meaning that the contents of the course (FA) are presented in a highly objective and contained fashion, with the explanation of theory and its direct application to real life financial accounting tasks heavily drawing on facts ${ }^{4}$. In contrast, Lecturer A's subject (CB) is much more subjective and allows negotiations based on personal beliefs and opinions. Consequently, Lecturer A's lectures are likely to outreach highly unplanned directions and opened ways, thus widening up the array of both specialized and informal lexicon that may be needed in conversation and which the teacher may not have prepared in advance. Accordingly, Lecturer B's linguistic repertoire could be more confined to the key factual contents of the field, which she commands expertly, not presenting evident and tangible language problems that require a switch to her L1.

All in all, results also make it fair to say that the seeming contrasting differences in the use of both lecturers' codeswitching may also be closely tied to their teaching style and personality. As teachers, each lecturer has 
her own idiosyncracy, unquestionably affecting how the teaching and learning process unravels in their own classrooms.

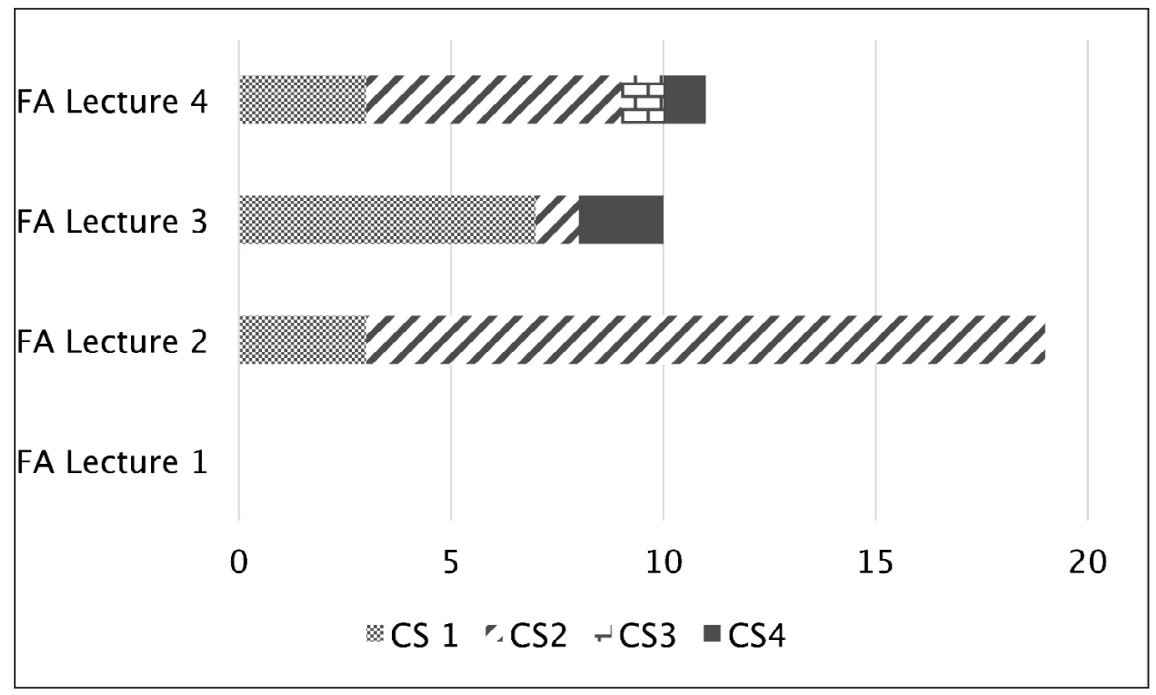

Graph 4. Codeswitching in Lecturer B's discourse (n)

\section{Conclusions and Implications}

This research attempts to throw some light on lecturers' discourse practices in EMI university settings by analyzing the pedagogical purposes behind codeswitching. In light of RQ1, results have shown that switching from English, the language of instruction, to Spanish, the L1 of the teachers and most of the students in the lessons is a quite common practice and responds to four main pedagogical goals ranking in the following order of frequency: (i) to construct knowledge, (ii) to manage the classroom, (iii) to express personal or affective meaning, and (iv) to establish interpersonal relations. Of the different instances of codeswitching that support these goals, there are two belonging to the construction of knowledge that stand out. The first one has to do with the need to resort to the L1 as the result of facing L2 linguistic difficulties. Interestingly, these language burdens, more often than not, appear to be more related to the everyday language, which indicates that, as experts of their own discipline, teachers are well aware of

ELIA 18, 2018, pp. 105-135 DOI: http://dx.doi.org/10.12795/elia.2018.118.05 
their field terminology. Therefore, they may be in need of developing their basic interpersonal communicative skills (BICS) more than their cognitive academic language proficiency (CALP). ${ }^{5}$ Such pressing lack could be taken into account to be included in EMI teacher development programs. The second pedagogical use worth highlighting is teacher's deliberate decision of providing learners with key disciplinary terminology in both languages (L1 and L2). This would benefit students in their learning and their future employability in a globalized world while may counteract the yet controversial claim of a possible loss of content knowledge in the L1 when studying through a L2.

Regarding RQ2, contrasting uses of the pedagogical purposes behind codeswitching practices have been observed. The reasons that could possibly be tied to this finding include the differing nature of the disciplines being taught coupled with teacher's own personality and teaching styles. In spite of this, results have yielded a similar tendency related to the very limited number of codeswitching instances to establish interpersonal relations among classroom participants. In fact, it results thought-provoking that the lecturers under study do not ever resort to this discourse practice to, for example, show appreciation and include different sociocultural identities considering the heterogeneity of their lessons in terms of students backgrounds. Once again, teachers may not be well aware of the potential of a multicultural and multilingual classroom. Diversity in terms of students' different linguistic and cultural backgrounds should be valued and used as a teaching resource (Carroll, 2015). In this respect, a downside of codeswitching practices becomes noticeable. It is important to realize that the use of codeswitching could be a hindrance if students lack enough knowledge or competence in the L2 to understand the information offered through that language (Sánchez-García, 2016). In these tertiary education settings in which English works as the lingua franca, not all students share linguistic backgrounds. Therefore, they could find themselves missing important content and language information as derived from teacher use of codeswitching to or from a language they may not fully master. It is then deemed crucial to raise lecturers' awareness of this discourse practice for them to analyze the possible impact of their codeswitching on their students' learning process. A possible course of action to be taken could entail helping them identify other types of discourse strategies that could also be beneficial for their teaching and which would rely on the lingua franca shared by all classroom participants, for example approximation or

ELIA 18, 2018, pp. 105-135 DOI: http://dx.doi.org/10.12795/elia.2018.i18.05 
circumlocution (Sánchez-García, 2016). So once again, raising teacher awareness and facilitating the effective incorporation and successful exploitation of codeswitching could be considered for EMI teacher development programs.

The study of two lecturers has allowed a small-scale analysis and comparison of the pedagogical functions behind their codeswitching practices to find out that their frequency of use as well as their motivations vary regarding the discourse of the two lecturers. The reason for this fact could be closely tied to lecturers' own teaching styles and language idiosyncrasies together with the different needs placed by the different academic fields. The fact that the main limitation of the study may precisely be its very small sample makes it possible to suggest further research that would look into the pedagogical aims of codeswitching as articulated in a larger corpus of EMI lecturers teaching the same and different academic disciplines. Likewise, it may be interesting to explore the phenomenon of codeswitching considering the students' perspective. That way the cautious interpretation of the current results could be complemented, allowing a better picture of the actual uses of codeswitching in EMI contexts and the possible teaching and learning needs deriving from it.

\section{Notes}

${ }^{1}$ In this study L2 is used to refer to foreign and/or second language interchangeably.

2 According to Vygostky (1978) ZPD is the distance between what a learner can do on his/her own and what he/she can achieve with the help and/or guidance of a more skilled person, for example, a teacher or a more capable fellow student.

${ }^{3}$ There are some Erasmus students attending the lessons for whom English may not work as a foreign, but as a second language.

${ }^{4}$ Research accounting for the language of the different school disciplines (see Biglan, 1973; Bernstein, 1999; Neumann, Parry \& Becher, 2002).

5 The acronyms BICS and CALP were introduced by Cummins (1979) to distinguish between the social language used in everyday conversations (BICS), and the specific linguistic competence required to understand and perform in the academic world (CALP).

ELIA 18, 2018, pp. 105-135 DOI: http://dx.doi.org/10.12795/elia.2018.i18.05 


\section{References}

Auer, P. (1998). Code-switching in conversation: language, interaction, and identity. London: Routledge.

Baker, C. (2006). Foundations of bilingual education and bilingualism. Clevedon: Multilingual Matters.

Barnard, R., \& McLelland, J. (2014). Code switching in university English language classes: Asian perspectives. Bristol/England: Multilingual Matters.

Bernstein, B. (1999). Vertical and horizontal discourse: An essay. British Journal of Sociology of Education, 20(2), 157-173.

Biglan, A. (1973). Relationships between subject matter characteristics and the structure and output of university departments. Journal of Applied Psychology, 57(3), 204-213.

Bista, K. (2010). Factors of code switching among bilingual English students in the university classroom: a survey. English for Specific Purpose World, 29(9), 1-18.

Blom, J. P., \& Gumperz, J. (1972). Social meaning in linguistic structures: code switching in Northern Norway. In J. Gumperz \& D. Hymes (Eds.), Directions in sociolinguistics: the ethnography of communication (497434). New York: Holt, Rinehart and Winston.

Cahyani, H., de Courcy, M., \& Barnett, J. (2018). Teachers' code-switching in bilingual classrooms: exploring pedagogical and sociocultural functions. International Journal of Bilingual Education and Bilingualism, 21(4), 465479.

Canagarajah, S. (1995). Functions of code Switching in the ESL classrooms: socializing bilingualism in Jaffna. Journal of Multicultural and Multilingual Development, 16(3), 173-196.

Canagarajah, S. (2011). Translanguaging in the classroom: emerging issues for research and pedagogy. Applied Linguistics Review, 2, 1-27.

Carroll, J. (2015). Tools for teaching in an educationally mobile world. London: Routledge.

ELIA 18, 2018, pp. 105-135 DOI: http://dx.doi.org/10.12795/elia.2018.i18.05 
Cook, V. (2001). Using the first language in the classroom. Canadian Modern Language Review, 57(3), 402-423.

Creese, A., \& Blackledge, A. (2010). Translanguaging in the bilingual classroom: a pedagogy for learning and teaching? The Modern Language Journal, 94(1), 103-115.

Cummins, J. (1979). Cognitive/academic language proficiency, linguistic interdependence, the optimum age question and some other matters. Working Papers on Bilingualism, 19, 121-129.

Dafouz, E. (2006). Solidarity strategies in CLIL university lectures: teachers' use of pronouns and model verbs. Vienna English Working Papers, 15(3), 9-15.

Dafouz, E., \& Núñez, B. (2010). Metadiscursive devices in university lectures: a contrastive analysis of L1 and L2 teacher performance. In C. Dalton-Puffer, T. Nikula \& U. Smit (Eds.), Language use and language learning in CLIL classrooms (pp. 213-232). Amsterdam: John Benjamins.

Dörnyei, Z., \& Scott, M. (1997). Communication strategies in a second language: definitions and taxonomies. Language Learning, 47, 173-210.

Du Bois, J., Schuetze-Coburn, S., Cumming, S., \& Paolino, D. (1993). Outline of discourse transcription. In J. Edwards \& M. Lampert (Eds.), Talking data: transcription and coding in discourse research (pp. 45-89). Hillsdale/NJ: Lawrence Erlbaum.

Duff, P., \& Polio, C. (1990). How much foreign language is there in the foreign language classroom? Modern Language Journal, 74, 154-166.

Ellis, R. (1984). Classroom second language development. Oxford: Pergamon.

Ferguson, G. (2003). Classroom code-switching in post-colonial contexts: functions, attitudes and policies. AILA Review, 16(1), 38-51.

Ferguson, G. (2009). What next? Towards and agenda for classroom codeswitching research. International Journal of Bilingual Education and Bilingualism, 12(2), 231-241.

García, O. \& Wei, L. (2014). Translanguaging: language, bilingualism and education. New York: Palgrave Macmillan.

ELIA 18, 2018, pp. 105-135 DOI: http://dx.doi.org/10.12795/elia.2018.i18.05 
Guthrie, L. (1984). Contrasts in teachers' language use in a Chinese-English bilingual classroom. In J. Handscombe, R. Orem \& B. Taylor (Eds.), TESOL '83: the question of control (pp. 39-52). Washington D. C.: TESOL.

Hall, G., \& Cook, G. (2012). Own language use in language teaching and learning. Language Teaching, 45(3), 271-308.

Halliwell, S., \& Jones, B. (1991). On target teaching in the target language. London: Centre for Information on Language Teaching and Research.

Jingxia, L. (2010). Teachers' code-switching to the L1 in EFL classroom. The Open Applied Linguistics Journal, 3, 10-23.

Kasper, G., \& Kellerman, E. (1997). Communication strategies: psycholinguistic and sociolinguistic perspectives. London: Longman.

Lantolf, J., \& Thorne, S. (2006). Sociocultural theory and second language acquisition. In B. van Patten \& J. Williams (Eds.), Theories in second language (pp. 201-224).New Jersey: Erlbaum.

Leask, B. (2015). Internationalizing the curriculum. London: Routledge.

Levine, G. (2011). Code choice in the language classroom. Bristol: Multilingual Matters.

Li, W. (1998). The 'why', and 'how' questions in the analysis of conversational code switching. In P. Auer, Peter (Ed.), Code-switching in conversation: language, interaction, and identity (pp. 156-176). London: Routledge.

Li, W. (2005). How can you tell?: toward a common sense explanation of conversational code-switching. Journal of Pragmatics 37(3), 375-389.

Lightbown, P. (2001). Instruction: time to teach. TESOL Quarterly, 35, 598-599.

Lin, A. (2013). Classroom code-switching: three decades of research. Applied Linguistics Review, 4(1), 195-218.

Martín del Pozo, M. A. (2014). Aproximación lingüistico-didáctica al discurso académico de la clase magistral en la formación del profesorado universitario en contextos bilingües (Unpublished doctoral dissertation). Universidad Complutense de Madrid, Spain

ELIA 18, 2018, pp. 105-135 DOI: http://dx.doi.org/10.12795/elia.2018.i18.05 
Mazak, C. (2016). Introduction: theorizing translanguaging practices in higher education. In C. Mazak \& K. Carroll (Eds.), Translanguaging in higher education: beyond monolingual ideologies (1-10). Buffalo, NY/Bristol, UK: Multilingual Matters.

Mazak, C., \& Carroll, K. (2016). Translanguaging in higher education: beyond monolingual ideologies. Buffalo, NY/Bristol, UK: Multilingual Matters.

McDonald, C. (1993). Using the target language. Cheltenham: Mary Glasgow.

Milroy, L., \& Muysken, P. (1995). One speaker, two languages: cross-disciplinary perspectives on code-switching. Cambridge, UK: Cambridge University Press.

Modupeola, O. (2013). Code-switching as a teaching strategy: implications for English language teaching and learning in a multilingual society. Journal of Humanities and Social Science, 14(3), 92-94.

Moore, P., Márquez Fernández, M., \& Gutiérrez Rando, V. (2014). La optimización del discurso del aula en el aprendizaje integrado de contenidos y lengua. Magazin/Extra, 1, 44-49.

Myers-Scotton, C. (1998). Codes and consequences: choosing linguistic varieties. New York: Oxford University Press.

Neumann, R., Parry, S., \& Becher, T. (2002). Teaching and learning in their disciplinary contexts: A conceptual analysis. Studies in Higher Education, 27(4), 405-417.

Nikula, T. (2010). On effects of CLIL on a teacher's language use. In C. DaltonPuffer, T. Nikula \& U. Smit (Eds.), Language Use and Language Learning in CLIL Classrooms (pp. 179-204). Amsterdam: John Benjamins.

Nilep, C. (2006). Code switching in sociocultural linguistics. Colorado Research in Linguistics, 19, 1-22.

Poplack, S. (1980). Sometimes I'll start a sentence in Spanish y termino en español: towards a typology of code-switching. Linguistics, 18, 581-616.

Sánchez-García, D. (2016). A contrastive analysis of Spanish- and Englishmedium instruction in tertiary education: teacher discourse strategies in a spoken corpus. Universidad Complutense de Madrid (Doctoral dissertation).

ELIA 18, 2018, pp. 105-135 DOI: http://dx.doi.org/10.12795/elia.2018.i18.05 
Scott, V., \& de la Fuente, M. J. (2008). What is the problem? L2 learners' use of the L1 during consciousness-raising form-focused tasks. The Modern Language Journal, 92(1), 100-113.

Simon, D. (2001). Towards a new understanding of codeswitching in the foreign language classroom. In R. Jacobson (Ed.), Codeswitching Worldwide II (pp. 311-342). New York: Mouton de Gruyter.

Smit, U. (2018). Classroom discourse in EMI: on the dynamics of multilingual practices. In K. Murata (Ed.), Exploring ELF in EMI settings in higher education. Routledge.

Smit, U. (2007). ELF as medium of instruction: interactional repair in international hotel management education. In C. Dalton-Puffer \& U. Smit (Eds.), Empirical Perspectives on CLIL (pp- 227-252). Peter Lang: Frankfurt.

Stern, H. (1992). Issues and options in language teaching. Oxford University Press.

Storch, N., \& Wigglesworth, G. (2003). Is there a role for the use of the L1 in an L2 setting? TESOL Quarterly, 37(4), 760-770.

Swain, M., \& Lapkin, S. (2000). Task-based second language learning: the uses of the first language. Language Teaching Research, 4(3), 251-274.

Then, D. C., \& Ting, S. H. (2011). Code-switching in English and science classrooms: more than translation. International Journal of Multilingualism, 8(4), 299-323.

Unamuno, V. (2008). Multilingual switch in peer classroom interaction. Linguistics and Education, 19, 1-19.

Vygotsky, L. (1978). Mind in society: the development of higher psychological processes. Cambridge, MA: Harvard University Press.

Vygotsky, L. (1986). Thought and language. Cambridge, Massachusetts: The MIT Press.

Wei, L. (2011). Moment analysis and translanguaging space: discursive construction of identities by multilingual Chinese youth in Britain. Journal of Pragmatics, 43, 1222-1235.

ELIA 18, 2018, pp. 105-135～DOI: http://dx.doi.org/10.12795/elia.2018.i18.05 
Wertsch, J. (1998). Mind as action. New York: Oxford University Press.

Wilkerson, C. (2008). Instructors' use of English in the modern language classroom. Foreign Language Annals, 41(2), 321-320.

Williams, C. (2002). Extending bilingualism in the education system. Education and Lifelong Learning Committee ELL-06-02. Retrieved from http://www. assembly.wales/Committee \%20Documents/ELL \%2006-02(p.4) \%20 $\mathrm{Dr} \% 20 \mathrm{Cen} \% 20 \mathrm{Wi} 11$ iams \%20 paper-20032002 28970/3c91c7af00023d820000595000000000-English.pdf

Wood, D., Bruner, J., \& Ross, G. (1976). The role of tutoring in problem-solving. Journal of Child Psychology and Psychiatry, 17, 89-100.

Yin, R. (2003). Case study research: design and methods. Thousand Oaks, CA: Sage.

First version received: July, 2018

Final version accepted: October, 2018

ELIA 18, 2018, pp. 105-135 DOI: http://dx.doi.org/10.12795/elia.2018.i18.05 